\title{
REAKSI PASAR MODAL INDONESIA TERHADAP PENGUMUMAN KEMENANGAN DONALD TRUMP DALAM PILPRES AMERIKA SERIKAT 2016
}

\author{
Kadek Ria Kusumayanti ${ }^{1}$ \\ Anak Agung Gede Suarjaya ${ }^{2}$ \\ ${ }^{1,2}$ Fakultas Ekonomi dan Bisnis Universitas Udayana, Bali-Indonesia \\ Email : riakusuma95@gmail.com
}

\begin{abstract}
ABSTRAK
Penelitian ini bertujuan untuk mengetahui ada tidaknya abnormal return setelah peristiwa pengumuman kemenangan Donald Trump, dalam Pemilu Presiden Amerika Serikat 2016 pada saham LQ-45. Penelitian ini menggunakan pendekatan event study, yaitu pendekatan yang digunakan untuk menguji efisiensi pasar bentuk setengah kuat. Sampel yang digunakan dalam penelitian ini adalah perusahaan yang terdaftar pada indeks LQ-45. Expected return dalam penelitian ini dihitung menggunakan market-adjusted model. Berdasarkan hasil uji-t ditemukan bahwa peristiwa pengumuman kemenangan Donald Trump dalam Pilpres Amerika Serikat 2016 menimbulkan reaksi pasar. Reaksi pasar dapat dilihat dari adanya abnormal return signifikan, yaitu pada $\mathrm{H}+1, \mathrm{H}+3, \mathrm{H}+4$ dan $\mathrm{H}+5$. Ditemukannya abnormal return signifikan pada $\mathrm{H}+3, \mathrm{H}+4$ dan $\mathrm{H}+5$ berarti bahwa pasar tidak efisien karena reaksi terjadi berkepanjangan.
\end{abstract}

Kata Kunci : reaksi pasar, efisiensi pasar bentuk setengah kuat, peristiwa politik.

\begin{abstract}
The purpose of this research is to determine abnormal return which effected after announcement of Donald Trump winning on presidential election of United Stated 2016. This reseach use event study approaching, that used to test semi-strong market efficiency. Sample of this research are company that listed on LQ-45 index. Expected return in this study calculated using market-adjusted model. Based on t-test found that there is market reaction in the announcement of Donald Trump winning on the presidential election of United Stated 2016. Market reaction can be know from significant abnormal return in $H+1, H+3, H+4$ and $H+5$. Significant abnormal return in $H+3, H+4$, and $H+5$ imply market not efficient because there is long respons reaction.
\end{abstract}

Keywords: market reaction, semi-strong form market efficiency, political events. 


\section{PENDAHULUAN}

Pasar modal sebagai salah satu instrumen ekonomi tidak lepas dari pengaruh lingkungan ekonomi maupun non ekonomi. Menurut Altin (2015) pengaruh lingkungan ekonomi terdiri dari pengaruh lingkungan ekonomi makro dan mikro, sedangkan pengaruh lingkungan non ekonomi seperti adanya Pemilihan Presiden, Pileg, kekisruhan politik, adanya peperangan, pengumuman kabinet menteri, dan peristiwa lainnya juga berpengaruh terhadap fluktuasi harga saham. Pengaruh lingkungan non ekonomi, meskipun tidak berkaitan langsung dengan dinamika yang terjadi di pasar modal, namun tidak dapat terpisahkan dari aktivitas di pasar modal (Diniar dan Kiryanto, 2015).

Salah satu faktor non ekonomi yang memiliki dampak di pasar modal suatu negara adalah peristiwa politik (Chien et al., 2014). Peristiwa politik merupakan salah satu peristiwa yang berpengaruh terhadap operasi pasar saham suatu negara secara luas. Peristiwa politik memiliki dampak positif dan juga negatif bagi kestabilan iklim investasi, sehingga mempengaruhi kepercayaan investor baik dalam dan luar negeri untuk berinvestasi di pasar modal (Ramesh dan Rajumesh, 2015). Waterschoot (2013) menyatakan bahwa peristiwa politik dan pasar keuangan dapat saling mempengaruhi yaitu melalui peran media massa.

Dari berbagai peristiwa politik yang terjadi di dunia, salah satu peristiwa yang menjadi tranding topic di berbagai media massa pada akhir tahun 2016, yaitu Pemilihan Presiden Amerika Serikat untuk periode 2017-2021. Sebagai negara dengan kekuatan dominan dalam kekuatan militer, kekuatan ekonomi, 
mata uang, sumber dan tujuan investasi, teknologi, isu politik dan isu sosiologis, pergantian presiden Amerika Serikat akan memiliki dampak besar bagi pasar global (Boomgaarden et al., 2012). Pemilu di negara Paman Sam ini semakin menarik perhatian publik, setelah Donald Trump dari Partai Republik dinyatakan berhasil menang mengalahkan Hilary Clinton dari Partai Demokrat. Berdasarkan hasil hitung cepat, Donald Trump memperoleh 276 electoral collage dan Hillary Clinton hanya mendapatkan 218 electoral collage.

Pengumuman kemenangan Donald Trump sebagai Presiden Amerika Serikat ke-45 mengejutkan masyarakat, karena banyak pihak memprediksi bahwa Hilary Clinton yang akan memenangkan pemilu. Terpilihnya Donald Trump sebagai Presiden Amerika Serikat berdampak negatif terhadap pasar modal secara global. Hal ini karena Trump dikenal sebagai presiden yang penuh kontroversi, misalnya mendapat berbagai tuduhan pelecehan seksual, tidak membayar pajak selama bertahun-tahun, mengancam akan melarang warga muslim masuk ke Amerika, mengancam akan mengusir para imigran ilegal (Wagner et al., 2017). Kontroversi lainnya yaitu terkait kebijakan ekonomi Trump yang anti perdagangan bebas untuk melindungi industri dalam negeri AS. Kebijakan Trump yang anti perdagangan bebas itu, diyakini menyebabkan ekonomi global semakin melambat (Wolfers dan Zitzewitz, 2016). Berikut pada Gambar 1 ditampilkan grafik persentase perubahan beberapa indeks pasar modal di dunia. 
Gambar 1

Grafik Persentase Perubahan Indeks Pasar Modal di Dunia

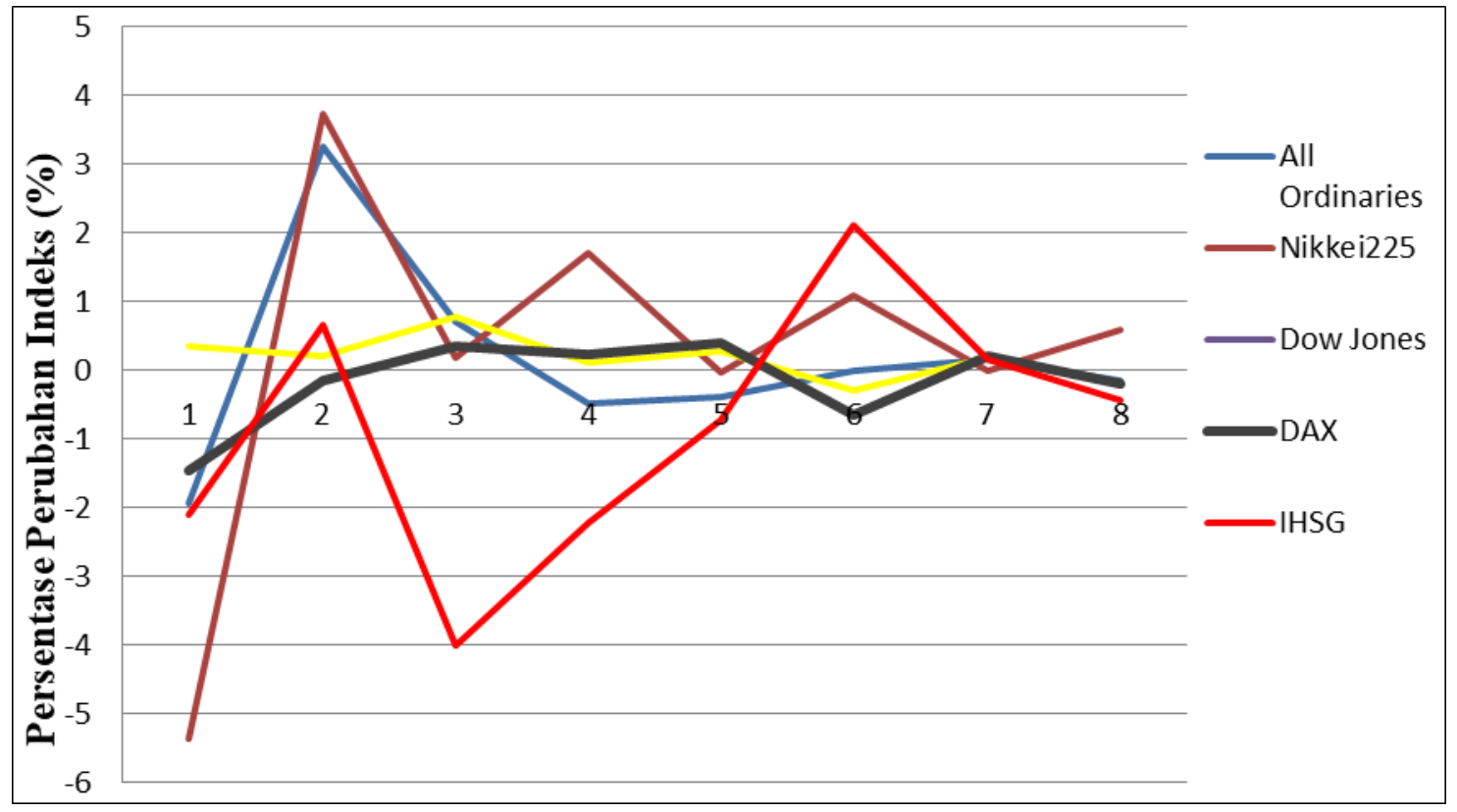

Sumber: Data diolah, 2017

Di Indonesia, Trump effect menyebabkan sebagian besar sekuritas di pasar modal mengalami penurunan harga saham. Dalam tempo.co.id yang ditulis oleh Kusumastuti (2016) menyatakan bahwa dari 538 saham yang diperdagangkan di Bursa Efek, sebanyak 56 saham menguat, 235 saham melemah, 68 saham stagnan, dan sisanya belum diperdagangkan. Pada saat pengumuman Donald Trump, sepuluh indeks sektoral melemah. Berikut pada Gambar 2 ditampilkan grafik persentase perubahan indeks sektoral. 


\section{Gambar 2}

\section{Grafik Persentase Perubahan Indeks Sektoral}

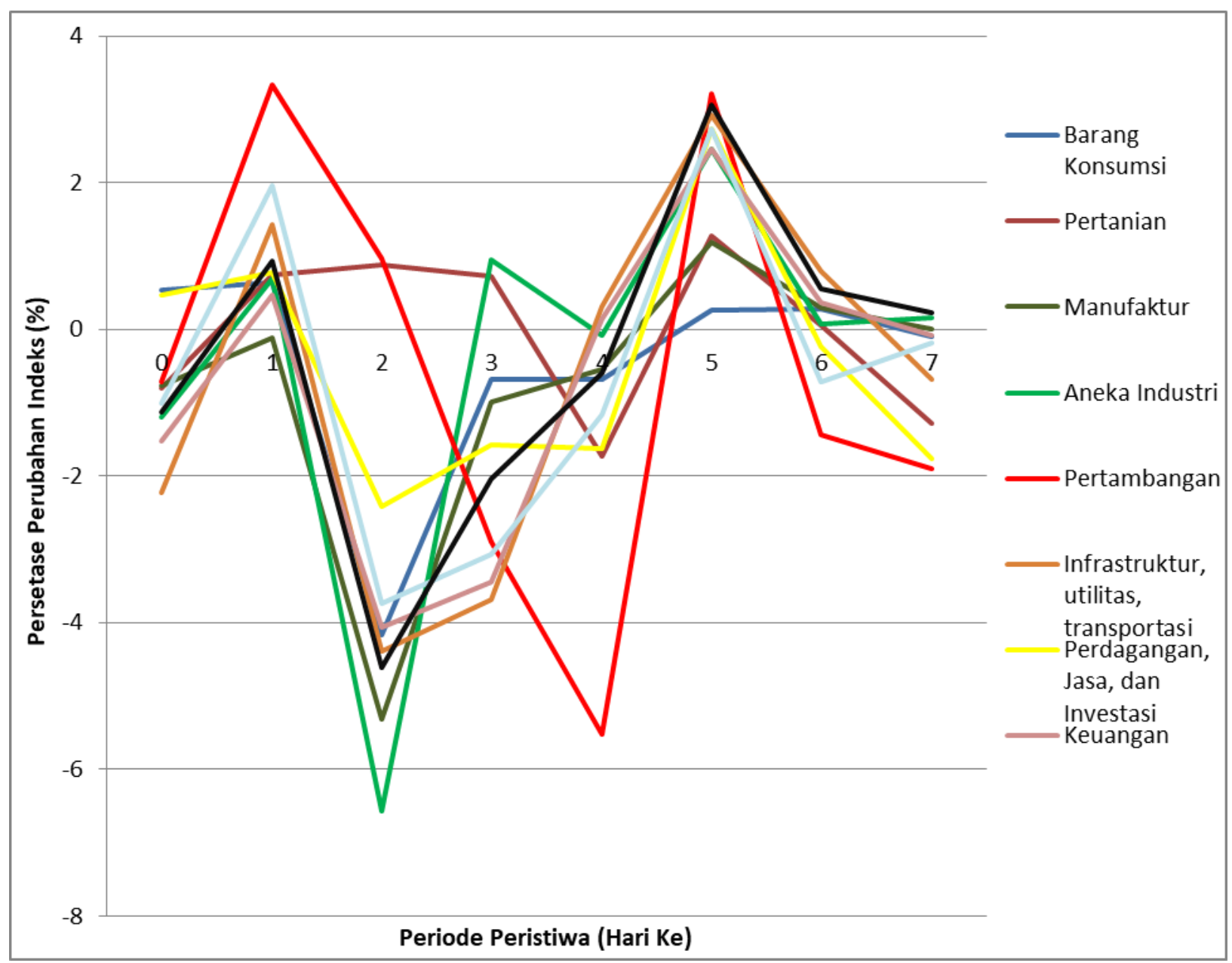

Sumber: Data diolah, 2017

Berdasarkan fenomena tersebut dapat diketahui bahwa peristiwa pengumuman kemenangan Donald Trump mempengaruhi harga saham. Peristiwa politik memang secara teori berpengaruh terhadap perkembangan bursa saham, tetapi untuk membuktikan secara analisis kuantitatif bahwa pengumuman kemenangan Donald Trump mempengaruhi pasar modal Indonesia masih perlu pengkajian. Hal ini karena, faktor politik dalam hal ini Pilpres adalah variabel laten yang bersifat tersembunyi, terpendam, dan tidak dapat diukur secara langsung sehingga perlu memperhatikan dimensi (indikator) variabel itu. Oleh 
sebab itu, dalam penelitian ini ingin mengetahui secara kuantitatif apakah pasar modal Indonesia bereaksi terhadap Trump effect ini. Salah satu metode yang dapat digunakan yaitu pendekatan event study.

Event study dapat digunakan untuk menguji kandungan informasi dari suatu pengumuman serta dapat juga digunakan untuk menguji efisiensi pasar bentuk setengah kuat (Jogiyanto, 2015:623). Menurut Arde (2017) pendekatan event study pada mulanya lebih memfokuskan pembahasannya mengenai corporate event saja. Sekarang aplikasi terhadap event study telah berkembang. Pengujiannya tidak terbatas tentang peristiwa internal perusahaan saja, tapi juga menyentuh aspek ekonomi makro, keuangan hingga politik. Penelitian ini meneliti peristiwa yang tidak bersifat corporate event, yaitu peristiwa politik pengumuman kemenangan Donald Trump dalam Pilpres Amerika Serikat.

Pengujian tentang reaksi pasar berhubungan dengan efisiensi pasar. Menurut (Tandelilin, 2010:221) jika pasar efisien, maka harga sekuritas akan secara cepat menyesuaikan akibat adanya informasi penting yang berhubungan dengan sekuritas, sedangkan pasar yang tidak efisien harga sekuritas kurang mencerminkan semua informasi tersedia, atau terdapat lag dalam proses penyesuaian harga, oleh karena itu investor memiliki peluang untuk memperoleh keuntungan dengan memanfaatkan situasi lag tersebut. Jogiyanto (2015:624) menyatakan bahwa, jika pengumuman memiliki kandungan informasi, maka diharapkan pasar akan bereaksi pada waktu pengumuman tersebut diterima oleh pasar. Reaksi ini dapat diukur menggunakan abnormal return. 
Samsul (2015:233) menyatakan bahwa abnormal return dapat terjadi sebelum suatu informasi diterbitkan dan dapat juga terjadi setelah informasi diterbitkan. Penelitian ini, meneliti ada tidaknya abnormal return setelah peristiwa pengumuman kemenangan Donald Trump saja, karena berdasarkan hasil penelitian sebelumnya yaitu Disertasi Manullang yang meneliti mengenai reaksi pasar modal terhadap 22 peristiwa politik yang terjadi selama kurun waktu 1996 sampai 2003, menunjukkan bahwa abnormal return yang signifikan hanya diperoleh saat event day dan post event day (Jogiyanto, 2005:87).

Penelitian ini menggunakan indeks LQ-45 sebagai sampel, karena rata-rata persentase perubahan indeks LQ-45 selama periode pengamatan yaitu tanggal 9 November 2016 hingga tanggal 18 November 2016 memiliki nilai terkecil dibandingkan indeks lainnya yaitu sebesar $-0,90$ persen. Persentase perubahan indeks ini menunjukkan persentase dari actual return yang diperoleh selama periode peristiwa. Ditemukannya nilai yang terkecil dibanding indeks lainnya, menunjukkan bahwa meskipun indeks LQ-45 merupakan kumpulan perusahaan yang memiliki fundamental dan tingkat likuiditas yang baik, tetapi akibat adanya peristiwa pengumuman kemenangan Donald Trump, indeks LQ-45 memiliki nilai persentase perubahan indeks terkecil dibanding indeks lainnya. Tentunya hal ini akan merugikan investor jika tidak menganalisis dampak suatu peristiwa politik terhadap saham LQ-45 lebih lanjut, karena menurut Hidayah (2015) pada dasarnya, tujuan investor berinvestasi pada saham LQ-45 adalah memperoleh return yang lebih besar dibandingkan risiko yang dihadapi. Berikut pada Gambar 3 ditampilkan gambar perbandingan rata-rata persentase perubahan indeks di BEI. 


\section{Gambar 3}

Grafik Rata-rata Persentase Perubahan Indeks di BEI

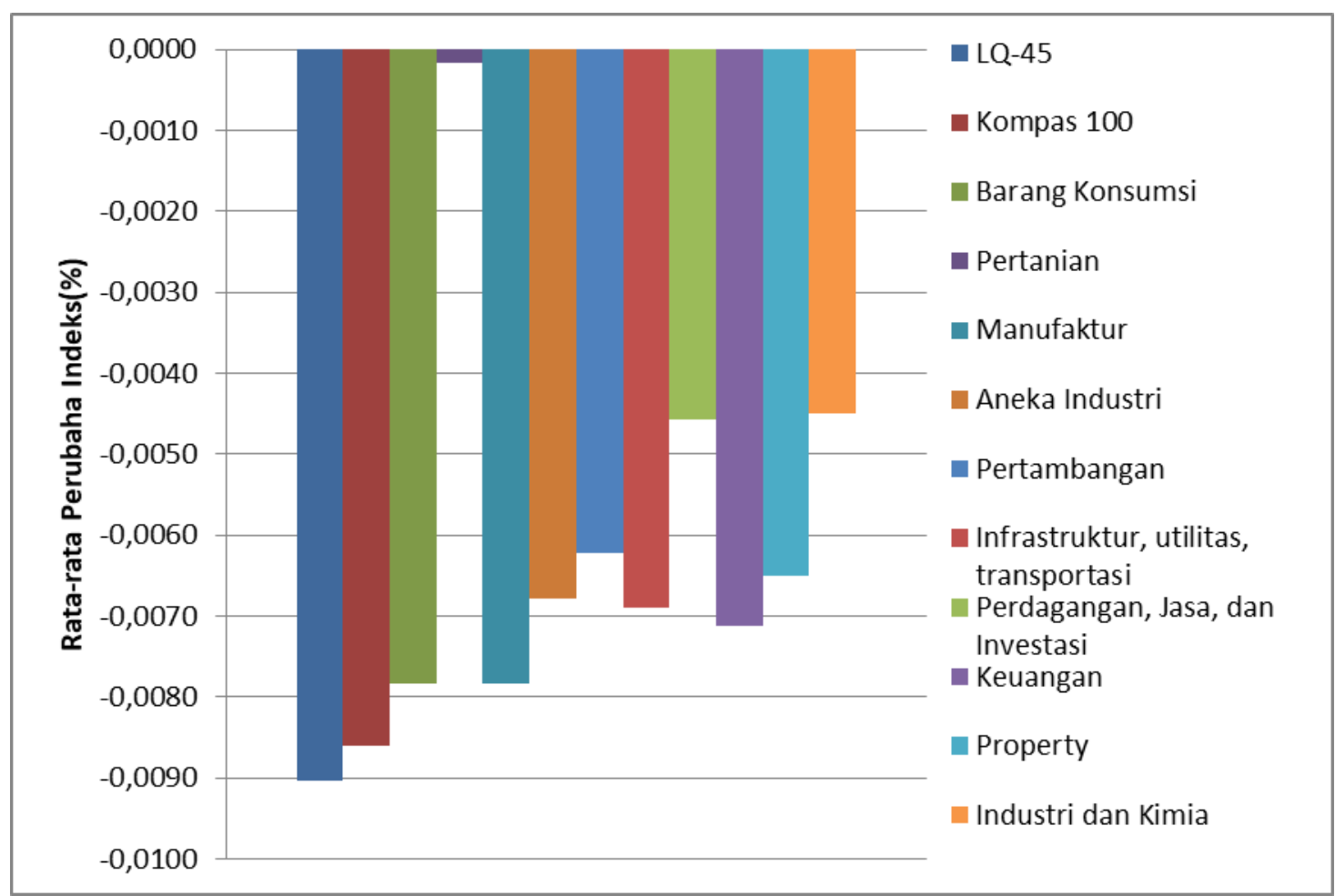

Sumber: Data diolah, 2017

Selain fenomena yang telah dipaparkan, salah satu alasan yang melatar belakangi penelitian ini adalah adanya research gap penelitian terdahulu yang telah meneliti reaksi pasar akibat adanya peristiwa politik. Penelitian Ghanem dan Rosvall (2014), Hatmanti dan Bambang (2017), Mahmood et al., (2014), Najaf et al., (2014), Kabiru et al., (2015), Pamungkas dkk., (2015), Ramesh dan Rajumesh (2015), Sasongko dkk., (2015), Yuliana dan Sudana (2015) mendapatkan hasil bahwa terdapat abnormal return yang signifikan pada periode setelah peristiwa politik yang diteliti. Sedangkan hasil yang berbeda ditemukan dalam penelitian Hung (2013), Octafilia (2016), Murekachiro (2014), Yuniarthi dan Sujana (2016) dan Wong dan Hooy (2016) menemukan hasil bahwa tidak terdapat abnormal return yang signifikan pada periode setelah peristiwa politik yang diteliti. 
Berdasarkan uraian latar belakang serta hasil penelitian terdahulu yang berbeda, menarik untuk dilakukan penelitian serupa.

Berdasarkan latar belakang permasalahan yang telah dibahas, maka rumusan masalah dalam penelitian ini adalah apakah terdapat abnormal return setelah peristiwa pengumuman kemenangan Donald Trump, dalam Pemilu Presiden Amerika Serikat 2016 pada saham LQ-45?. Tujuan dari penelitian ini adalah untuk mengetahui ada tidaknya abnormal return setelah peristiwa pengumuman kemenangan Donald Trump, dalam Pemilu Presiden Amerika Serikat 2016 pada saham LQ-45.

Manfaat yang diharapkan dalam penelitian ini yaitu mampu memberikan manfaat teoritis maupun manfaat praktis, untuk manfaat teoritis, hasil penelitian ini diharapkan dapat menghasilkan bukti empiris tentang pengujian efisiensi pasar bentuk setengah kuat dan reaksi pasar modal terhadap pengumuman kemenangan Donald Trump dalam Pilpres Amerika Serikat, sedangkan manfaat praktis hasil penelitian ini diharapkan dapat membantu praktisi, emiten, dan investor, dalam memberikan informasi mengenai peristiwa politik, agar secara tepat dapat memilah dan menganalisis informasi-informasi yang relevan untuk dijadikan pertimbangan dalam pengambilan keputusan, sehingga dapat menjadi pembelajaran untuk mengantisipasi dan memprediksi kemungkinan-kemungkinan dari peristiwa politik yang akan terjadi mendatang.

Tandelilin (2010:2) menyatakan bahwa investasi adalah komitmen atas sejumlah dana atau sumber daya lainnya yang dilakukan pada saat ini, dengan tujuan memperoleh sejumlah keuntungan di masa datang. Alasan utama seseorang 
berinvestasi yaitu untuk mendapatkan keuntungan. Dalam konteks manajemen investasi, perlu dibedakan antara return harapan dan return aktual. Return harapan merupakan return yang diantisipasi investor di masa datang, sedangkan return yang terjadi atau return aktual merupakan return yang diperoleh investor pada masa lalu (Tandelilin, 2010:10).

Saham adalah kertas yang tercantum dengan jelas nilai nominal, nama perusahaan, dan diikuti dengan hak dan kewajiban yang telah dijelaskan kepada setiap pemegangnya (Fahmi, 2012:81). Hartono (2015:188) menyatakan harga saham adalah harga suatu saham yang terjadi di pasar bursa pada saat tertentu yang ditentukan oleh permintaan dan penawaran saham yang bersangkutan di pasar modal. Harga saham yang terjadi di pasar modal selalu berfluktuasi dari waktu ke waktu. Faktor-faktor yang mempengaruhi fluktuasi harga saham dapat berasal dari internal dan eksternal perusahaan.

Efficient Market Hypothesis (EMH), diperkenalkan oleh Markowitz pada tahun 1952 dan kemudian dinamai oleh Fama tahun 1970, mengasumsikan bahwa pasar dikatakan efisien jika harga-harga sekuritasnya dapat mencerminkan secara penuh informasi yang tersedia. Konsep pasar efisien menjelaskan tentang proses penyesuaian harga saham suatu perusahaan menuju harga keseimbangan yang baru. Pada pasar yang efisien, harga sekuritas secara cepat akan menyesuaikan akibat adanya informasi yang berhubungan dengan sekuritas tersebut, sedangkan pasar yang tidak efisien harga sekuritas kurang mencerminkan semua informasi tersedia, atau terdapat lag dalam proses penyesuaian harga, sehingga investor 
memiliki peluang untuk mendapatkan keuntungan dengan memanfaatkan situasi lag itu (Tandelilin, 2010:221).

Jogiyanto $(2015 ; 586)$ mengemukakan bentuk efisiensi pasar dapat ditinjau dari segi ketersediaan informasi dan juga dari kecanggihan pelaku pasar dalam melakukan pengambilan keputusan. Pasar efisien yang ditinjau dari sudut informasi saja disebut dengan efisiensi pasar secara informasi (informationally efficient market). Pasar efisien yang ditinjau dari segi kecanggihan pelaku pasar dalam mengambil keputusan berdasarkan informasi yang tersedia disebut dengan efisiensi pasar secara keputusan (decissionally efficient market).

Jogiyanto (2015:623) menjelaskan bahwa event study adalah studi yang mempelajari reaksi pasar terhadap suatu peristiwa (event) yang informasinya dipublikasikan sebagai suatu pengumuman. Event study juga dapat digunakan untuk menguji efisiensi pasar bentuk setengah kuat. Secara lebih spesifik studi peristiwa menyelidiki respon pasar terhadap kandungan informasi dari suatu pengumuman peristiwa tertentu.

Peristiwa politik merupakan salah satu faktor yang mempengaruhi aktivitas pasar modal. Mayo (2016:391) menyatakan bahwa informasi yang terkandung dalam dinamika politik yang terjadi pada suatu negara, akan diserap oleh para pelaku pasar modal. Pemilihan Umum (Pemilu) dikategorikan sebagai suatu peristiwa politik yang memiliki pengaruh yang signifikan terhadap aktivitas ekonomi dan keuangan karena Pemilu merupakan sebuah mekanisme redistribusi kekuasaan yang hasilnya akan menentukan wajah pemerintahan dan orientasi kebijakan negara selama beberapa tahun mendatang (Saputra, 2016). 
Abnormal return adalah selisih antara actual return dengan expected return (Jogiyanto, 2015:647). Menurut Jogiyanto (2015:205) actual return adalah return yang sudah terjadi yang dapat dihitung berdasarkan data historis, sedangkan expected return adalah return yang diestimasikan dari keuntungan yang diharapkan oleh investor (Jogiyanto, 2015:648).

Tandelilin (2010:565) menyatakan bahwa pada hipotesis pasar efisien, pasar akan memberi respon negatif untuk berita buruk dan respon positif untuk berita baik. Respon pasar tersebut tercermin dari abnormal return positif (berita baik) dan abnormal return negatif (berita buruk). Samsul (2015:233) menyatakan bahwa abnormal return dapat terjadi sebelum suatu informasi diterbitkan dan dapat juga terjadi setelah informasi diterbitkan. Menurut Jogiyanto (2005:87) Manullang adalah orang pertama yang melakukan penelitian dengan peristiwa jamak di Indonesia. Hasil penelitiannya menunjukkan bahwa terdapat abnormal return saat event day dan post event day, sedangkan untuk periode sebelum peristiwa tidak ditemukan adanya abnormal return.

Terdapat banyak penelitian yang telah dilakukan mengenai peristiwa non ekonomi, khususnya yang berkaitan dengan peristiwa politik terhadap abnormal return. Penelitian yang dilakukan oleh Ghanem dan Rosvall (2014), Hatmanti dan Bambang (2017), Mahmood et al., (2014), Najaf et al., (2014), Kabiru et al., (2015), Pamungkas dkk., (2015), Ramesh dan Rajumesh (2015), Sasongko dkk., (2015), Yuliana dan Sudana (2015) menemukan adanya abnormal return setelah periode peristiwa politik yang diteliti. 
Berdasarkan teori dan penelitian terdahulu tersebut, maka dapat dirumuskan hipotesis sebagai berikut:

Hipotesis (HI): terdapat abnormal return setelah peristiwa pengumuman kemenangan Donald Trump, dalam Pemilu Presiden Amerika Serikat 2016 pada saham LQ-45.

\section{METODE PENELITIAN}

Desain dalam penelitian ini menggunakan metode penelitian kuantitatif. Desain penelitian kuantitatif dalam penelitian ini didukung dengan menggunakan pendekatan studi peristiwa (event study). Pendekatan ini akan digunakan untuk menganalisis reaksi pasar modal Indonesia terhadap peristiwa pengumuman kemenangan Donald Trump. Penelitian ini dilakukan di BEI melalui situs resminya (www.idx.co.id). Periode pengamatan dalam penelitian ini selama 8 hari, yaitu tanggal 9 November 2016 sampai 18 November 2016.

Obyek penelitian dalam penelitian ini adalah harga saham masing-masing perusahaan yang terdaftar dalam indeks LQ-45 selama periode peristiwa pengumuman kemenangan Donald Trump. Variabel-variabel yang digunakan pada penelitian ini antara lain actual return, expected return, dan abnormal return. Actual return merupakan return yang terjadi pada waktu ke-t yang merupakan selisih harga sekarang relatif terhadap harga sebelumnya. Expected return adalah return yang diharapkan investor yang akan diperoleh dimasa yang akan datang. Abnormal return merupakan kelebihan dari return yang sesungguhnya terjadi terhadap return normal (Jogiyanto, 2015:647). 
Jenis data yang digunakan dalam penelitian ini adalah data kuantitatif. Sumber data yang digunakan dalam penelitian ini adalah sumber data sekunder, yaitu berupa data historis seluruh perusahaan yang terdaftar pada indeks LQ-45 saat event day dan post event day.

Populasi dalam penelitian ini adalah seluruh perusahaan yang terdaftar dalam indeks LQ-45 saat periode pengamatan. Sampel penelitian yang menjadi objek penelitian ini adalah perusahaan yang terdaftar dalam saham indeks LQ-45. Metode pengambilan sampel yang digunakan dalam penelitian ini menggunakan teknik sampling jenuh. Metode pengumpulan data yang digunakan untuk memperoleh data pada penelitian ini adalah metode dokumenter atau dengan cara menelusuri data historis.

Teknik analisis data yang digunakan adalah uji-t. Langkah-langkah uji-t mengenai signifikansi abnormal return adalah sebagai berikut:

1. Menghitung return sesungguhnya

Actual return dihitung dengan rumus sebagai berikut (Jogiyanto, 2015:648): Rit= Error! Reference source not found.

2. Menghitung return ekspektasi

Penelitian ini menggunakan market-adjusted model dalam mengitung return ekspektasi, dengan rumus sebagai berikut (Jogiyanto, 2015: 269):

$\mathrm{E}\left(\mathrm{R}_{\mathrm{it}}\right)=\mathrm{R}_{\mathrm{mt}}$

Return market $\left(\mathrm{R}_{\mathrm{m}}\right)$ dihitung menggunakan ukuran IHSG, dengan rumus sebagai berikut (Jogiyanto, 2015: 653):

$\mathrm{R}_{m t}=$ Error $!$ Reference source not found. 
3. Menghitung abnormal return

Abnormal return dihitung dengan menggunakan rumus sebagai berikut (Jogiyanto, 2015: 648):

$\mathrm{AR}_{\mathrm{it}}=\mathrm{R}_{\mathrm{it}}-\mathrm{E}\left(\mathrm{R}_{\mathrm{it}}\right)$

4. Melakukan uji hipotesis

Hipotesis dihitung dan diolah menggunakan uji-t. Tahapan uji-t adalah sebagai berikut:

a. Merumuskan hipotesis :

Ho : tidak terdapat abnormal return setelah peristiwa pengumuman kemenangan Donald Trump dalam Pemilu Presiden Amerika Serikat 2016 pada saham LQ-45.

HI : terdapat abnormal return setelah peristiwa pengumuman kemenangan Donald Trump dalam Pemilu Presiden Amerika Serikat 2016 pada saham LQ-45.

b. Menghitung rata-rata abnormal return

Penelitian ini menggunakan pendekatan market-adjusted model untuk menghitung expected return, sehingga untuk menghitung standar deviasinya dilakukan secara agregat untuk semua sekuritas (crosssection), dengan rumus sebagai berikut (Jogiyanto, 2015: 660):

Error! Reference source not found.

Keterangan:

Error! Reference source not found. = rata-rata abnormal return

$\mathrm{k} \quad=$ jumlah sampel 
Error! Reference source not found. = abnormal return

c. Menghitung kesalahan standar deviasi

Dalam menghitung kesalahan standar estimasi, didasarkan pada deviasi standar abnormal return dari k-sekuritas secara cross section selama periode peristiwa dengan rumus sebagai berikut (Jogiyanto, 2015: 681):

$\mathrm{KSE}_{\mathrm{t}}=$ Error ! Reference source not found.. Error! Reference source not found.

Keterangan:

$\mathrm{KSE}_{\mathrm{t}}=$ kesalahan standar estimasi untuk hari ke-t di periode peristiwa

Error! Reference source not found. = abnormal return sekuritas ke-i untuk hari ke-t di periode peristiwa

Error! Reference source not found. = rata-rata abnormal return k-sekuritas untuk hari ke-t di periode peristiwa

$\mathrm{k} \quad=$ jumlah sekuritas

d. Menentukan tingkat signifikansi

Tingkat signifikansi yang digunakan adalah 5\%

e. Menghitung nilai t-hitung

Nilai t-hitung dihitung dengan menggunakan rumus sebagai berikut (Jogiyanto, 2015: 666) :

$\mathrm{t}=$ Error! Reference source not found. 
Keterangan :

$\mathrm{t} \quad=\mathrm{t}$-hitung

Error! Reference source not found. = rata-rata abnormal return

f. Membandingkan t-hitung dengan t-tabel

1. Jika nilai t-hitung Error! Reference source not found.-t-tabel dan t-hitung Error! Reference source not found. t-tabel, maka Ho ditolak dan HI diterima, artinya terdapat abnormal return pada saham LQ-45 setelah peristiwa pengumuman kemenangan Donald Trump dalam Pilpres Amerika Serikat 2016.

2. Jika nilai -t-tabel $<\mathrm{t}$-hitung $<\mathrm{t}$-tabel, maka Ho diterima dan HI ditolak, artinya tidak terdapat abnormal return pada saham LQ-45 setelah peristiwa pengumuman kemenangan Donald Trump dalam Pilpres Amerika Serikat 2016.

\section{HASIL DAN PEMBAHASAN}

Actual return dihitung mengunakan rumus $\mathrm{Rit}=\{(\mathrm{Pt}-\mathrm{Pt}-1) /(\mathrm{Pt}-1)\}$, dengan menggunakan harga saham penutupan (closing price). Secara keseluruhan selama 8 hari periode peristiwa pada indeks LQ-45 terdapat 360 nilai actual return. Dari 360 actual return selama periode peristiwa, sebesar 62,5 persen atau 225 actual return bernilai negatif, 27,78 persen atau 100 actual return bernilai positif, dan 9,72 persen atau 35 actual return bernilai nol. Pada Tabel 1 disajikan rekapitulasi komposisi hasil perhitungan actual return pada perusahaan LQ-45 selama periode peristiwa. 
Tabel 1

\section{Rekapitulasi Komposisi Actual Return Sekuritas Selama Periode Peristiwa}

\begin{tabular}{|c|c|c|c|c|}
\hline \multirow{2}{*}{ Hari Ke-t } & \multicolumn{3}{|c|}{ Jumlah Perusahaan } & \multirow{2}{*}{ Jumlah } \\
\hline & Min & Plus & Nol & \\
\hline 7 & 24 & 12 & 9 & 45 \\
\hline 6 & 22 & 18 & 5 & 45 \\
\hline 5 & 6 & 37 & 2 & 45 \\
\hline 4 & 32 & 6 & 7 & 45 \\
\hline 3 & 37 & 4 & 4 & 45 \\
\hline 2 & 39 & 6 & 0 & 45 \\
\hline 1 & 32 & 10 & 3 & 45 \\
\hline 0 & 33 & 7 & 5 & 45 \\
\hline Jumlah & 225 & 100 & 35 & 360 \\
\hline Persentase (\%) & 62,5 & 27,78 & 9,72 & 100 \\
\hline
\end{tabular}

Sumber : Data diolah, 2017

Berdasarkan Tabel 1 dapat diketahui bahwa selama periode peristiwa terdapat actual return yang nilainya negatif, positif dan nol. Actual return yang positif berarti bahwa adanya peningkatan harga pada $\mathrm{H} 0$ dari harga saham $\mathrm{H}-1$, actual return nol berarti bahwa harga saham pada H0 sama dengan H-1, sedangkan actual return negatif berarti bahwa harga saham H0 lebih rendah dibandingkan harga saham H-1. Actual return negatif lebih banyak daripada actual return positif yaitu sebesar 62,50 persen, hal ini berarti sebagian besar perusahaan selama periode peristiwa mengalami penurunan harga saham.

Expected return dihitung menggunakan pendekatan market-adjusted model, sehingga nilai expected return untuk masing-masing sekuritas sama dengan return indeks pasar. Gambar 4 menunjukkan bahwa setelah peristiwa pengumuman kemenangan Donald Trump, expected return juga menunjukkan pergerakan yang berfluktuatif. Pada $\mathrm{H} 0$ hingga $\mathrm{H}+1$ expected return mengalami kenaikan, sedangkan pada H+2 mengalami penurunan hingga mencapai -0,0401, kemudian 
mengalami kenaikan kembali dari $\mathrm{H}+3$ hingga $\mathrm{H}+5$, dan akhirnya mengalami penurunan pada $\mathrm{H}+6$ hingga $\mathrm{H}+7$.

Gambar 4

Grafik Pergerakan Expected Return

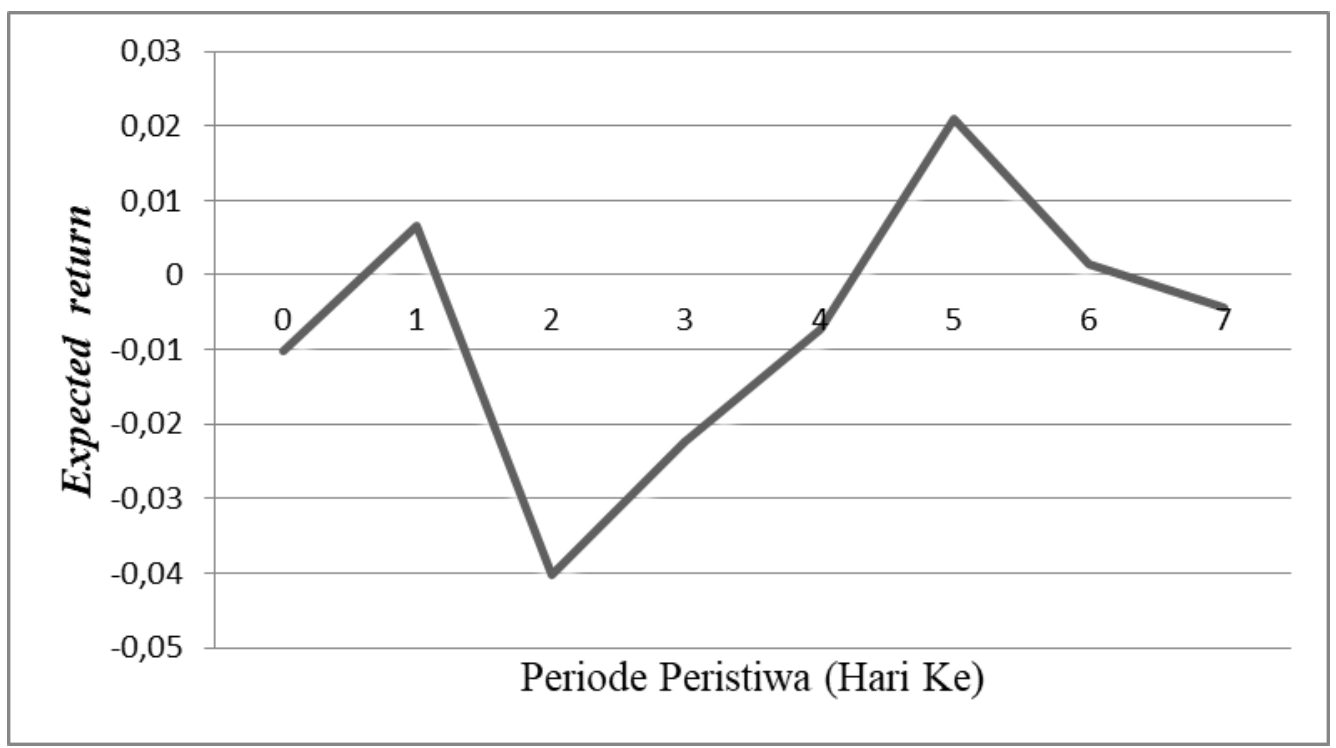

Sumber: Data diolah, 2017

Abnormal return merupakan selisih antara actual return dengan expected

return. Berdasarkan hasil perhitungan abnormal return selama periode peristiwa, terdapat abnormal return negatif dan positif. Secara keseluruhan selama periode peristiwa terdapat 360 nilai abnormal return. Abnormal return yang bernilai negatif jumlahnya lebih banyak dibandingkan dengan abnormal return yang bernilai positif. Nilai abnormal return yang bernilai positif sebanyak 166 atau sebesar 46,11 persen dan nilai abnormal return negatif sebanyak 194 atau sebesar 53,89 persen. Tabel 2 berikut menampilkan data rekapitulasi abnormal return pada perusahaan yang termasuk dalam indeks LQ-45. 
Tabel 2

Rekapitulasi Komposisi Abnormal Return Sekuritas Pada Periode Peristiwa

\begin{tabular}{cccc}
\hline \multirow{2}{*}{ Hari Ke-t } & \multicolumn{2}{c}{ Jumlah Perusahaan } & Total \\
& Min & Plus & \\
\hline 7 & 24 & 21 & 45 \\
6 & 27 & 18 & 45 \\
5 & 16 & 29 & 45 \\
4 & 29 & 16 & 45 \\
3 & 27 & 18 & 45 \\
2 & 31 & 14 & 45 \\
1 & 19 & 26 & 45 \\
0 & 21 & 24 & 45 \\
\hline Jumlah & 194 & 166 & 360 \\
\hline Persentase & 53,89 & 46,11 & 100 \\
(\%) & \multirow{2}{*}{ Sumber: Data Diolah, 2017} &
\end{tabular}

Langkah awal pengujian statistik yaitu melakukan perhitungan terhadap rata-rata abnormal return, kemudian menghitung kesalahan standar estimasi yang didasarkan pada deviasi standar abnormal return dari k-sekuritas secara cross section selama periode peristiwa. Selanjutnya adalah menghitung nilai t-hitung. Pengujian signifikansi terhadap abnormal return dilakukan dengan melakukan uji terhadap t-hitung selama periode peristiwa, kemudian nilai t-hitung dibandingkan dengan nilai t-tabel. Nilai t-tabel 2,014 (pada tingkat 5 persen). Berikut pada Tabel 3 disajikan t-hitung dan signifikansi abnormal return selama periode peristiwa. 
Tabel 3

T-hitung dan Signifikansi Abnormal Return Selama Periode Peristiwa

\begin{tabular}{cccc}
\hline Hari Ke-t & AAR & t-hitungg & Keterangan \\
\hline 7 & $-0,00257$ & $-1,1212$ & Ts \\
6 & $-0,0026$ & $-0,78693$ & Ts \\
5 & 0,01278 & 2,5933 & Sig \\
4 & $-0,014$ & $-3,16307$ & Sig \\
3 & $-0,0072$ & $-2,14375$ & Sig \\
2 & $-0,0037$ & $-0,54238$ & Ts \\
1 & 0,00772 & 2,018753 & Sig \\
0 & $-0,0004$ & $-0,07166$ & Ts \\
\hline \multicolumn{2}{c}{ Sumber: Data diolah, 2017}
\end{tabular}

Keterangan :

Ts : Tidak Signifikan

Sig : Signifikan pada tingkat 5 persen $(t>2,014$ dan $t<-2,014)$

Berdasarkan Tabel 3 dapat diketahui bahwa nilai hasil pengujian abnormal return secara statistik signifikan pada $\mathrm{H}+1, \mathrm{H}+3, \mathrm{H}+4, \mathrm{H}+5$, sedangkan untuk $\mathrm{H}+0, \mathrm{H}+1, \mathrm{H}+6$ dan $\mathrm{H}+7$ secara statistik tidak signifikan. Abnormal return negatif signifikan pada $\mathrm{H}+3$ dan $\mathrm{H}+4$ dengan nilai $-2,14375,-3,16307$, sedangkan abnormal return positif signifikan pada $\mathrm{H}+1$ dan $\mathrm{H}+5$ dengan nilai 2,018753 dan 2,5933 .

Dalam penelitian ini reaksi pasar yang diuji adalah reaksi pasar di sekitar peristiwa pengumuman kemenangan Donald Trump dalam Pilpres AS 2016 yaitu 7 hari setelah pengumuman. Reaksi pasar yang terjadi tercermin dari perubahan harga saham yang diukur menggunakan abnormal return. Berdasarkan hasil pengujian statistik ditemukan adanya abnormal return yang signifikan yaitu pada $\mathrm{H}+1, \mathrm{H}+3, \mathrm{H}+4, \mathrm{H}+5$, ini berarti terdapat reaksi pasar yang diakibatkan oleh peristiwa pengumuman kemenangan Donald Trump. Hal ini sejalan dengan Mayo (2016:391) yang menyatakan bahwa informasi yang terkandung dalam dinamika 
politik yang terjadi pada suatu negara, akan diserap oleh para pelaku pasar modal. Begitu pula dengan Deva et al., (2015) yang menyatakan bahwa salah satu variabel yang dapat mempengaruhi harga saham adalah peristiwa politik sehingga dapat mengindikasikan adanya abnormal return.

Reaksi pasar modal yang dilihat dari abnormal return yang diterima oleh investor disekitar hari-hari peristiwa tersebut, memperlihatkan kecepatan pasar dalam menyerap informasi yang diterima. Kecepatan reaksi pasar modal terhadap peristiwa tersebut bereaksi cepat karena terdapat abormal return yang signifikan pada satu hari $(\mathrm{H}+1)$ setelah peristiwa. Namun abnormal return muncul kembali pada $\mathrm{H}+3, \mathrm{H}+4$ dan $\mathrm{H}+5$ menunjukkan bahwa pasar tidak efisien, karena reaksi terjadi berkepanjangan, seperti yang dinyatakan oleh Tandelilin (2010:223) bahwa pasar yang efisien bentuk setengah kuat, abnormal return hanya terjadi di seputar pengumuman (publikasi) suatu peristiwa sebagai representasi dari respon pasar terhadap pengumuman tersebut. Abnormal return yang terjadi berkepanjangan (lebih dari 3 spot waktu) menunjukkan adanya respon pasar yang terlambat dalam menyerap informasi, sehingga dengan demikian dianggap pasar tidak efisien dalam bentuk setengah kuat.

Peristiwa kemenangan Donald Trump diduga merupakan bad news. Hal ini karena publik mengenal Donald Trump sebagai sosok presiden yang penuh kontroversi dan terdapat berbagai isu negatif mengenai Trump. Namun meskipun Trump effect diduga merupakan bad news, pada $\mathrm{H}+1$ dan $\mathrm{H}+5$ diperoleh abnormal return positif signifikan. Hasil yang bertentangan dengan hipotesis ini terjadi karena harga saham tidak hanya dipengaruhi oleh adanya suatu peristiwa politik 
saja, namun juga faktor-faktor lain baik dari intern dan ekstern perusahaan. Salah satu faktor yang kemungkinan mempengaruhi abnormal return positif pada $\mathrm{H}+1$ dan $\mathrm{H}+5$ adalah optimisme pemerintah terhadap fundamental ekonomi Indonesia. Ekonomi Indonesia tumbuh mencapai 5,02\% pada kuartal III 2016 dan pada kuartal IV diprediksi akan naik berkisar antara 5 persen sampai 5,4 persen (www.bi.go.id). Sri Mulyani menyatakan bahwa penurunan harga saham yang sempat terjadi sangat dipengaruhi oleh Trump effect dan hal tersebut merupakan hal yang wajar sebagai dampak dari reaksi shock investor akibat menangnya Donald Trump yang diluar prediksi dan sosoknya yang kontroversial. Namun Trump effect diyakini hanya bersifat sementara bagi pasar modal Indonesia. Indonesia diuntungkan dengan keberhasilan program tax amnesty, kebijakan Presiden Joko Widodo terkait pembangunan infrastruktur yang merata di seluruh wilayah Indonesia dan penguatan ekonomi nasional. Sehingga dengan adanya Trump effect, disaat pasar modal di negara lain mengalami penurunan harga saham tinggi yang berkisar antara 3 hingga 6 persen, namun untuk pasar modal di Indonesia walaupun sempat mengalami penurunan, tapi tidak sebesar penurunan seperti yang terjadi pada negara lain (Winarno, 2016).

Jika dilihat secara spesifik adanya abnormal return positif pada $\mathrm{H}+1$ kemungkinan terjadi karena pidato kemenangan Trump. Trump dalam pidatonya menyampaikan akan mengajak negara lain bekerja sama untuk memperkuat dan melipat gandakan pertumbuhan ekonomi AS. Hal ini tentunya bertentangan dengan pernyataan yang disampaikan ketika kampanye dan debat Pilpres, sehingga isi pidato tersebut disambut baik oleh investor dengan melakukan aksi 
beli kembali (Silitonga, 2016). Abnormal return positif pada $\mathrm{H}+5$ kemungkinan disebabkan karena adanya peristiwa penetapan Basuki Tjahaja Purnama sebagai tersangka dalam kasus penistaan agama. Penetapan status tersangka ini dinilai dapat meredam ketegangan politik dalam negeri karena dengan penetapan status tersangka ini berarti tidak akan ada demo lanjutan kembali. Hal ini menyebabkan kestabilan politik sudah mulai meningkat dan menarik investor kembali berinvestasi di Indonesia (Lestarini, 2016).

Pada $\mathrm{H}+3$ dan $\mathrm{H}+4$ ditemukan adanya abnormal return negatif signifikan. Hal ini terjadi kemungkinan karena pelemahan rupiah terhadap dolar hingga mencapai Rp 13.800 (Ariyanti, 2016). Jika kurs anjlok maka investor akan rugi, sehingga mereka menarik diri dari pasar modal dikarenakan aliran modal masuk ke Amerika Serikat, dan dianggap sebagai tempat yang lebih aman dari ketidakpastian. Rupiah melemah juga diakibatkan karena kekhawatiran terhadap dampak kebijakan Donald Trump. Beberapa kebijakan yang mempengaruhi respon negatif pasar modal Indonesia adalah kebijakan yang berkaitan dengan pajak, ekonomi, energi, dan suku bunga. Pada situs resmi kampanye Donald Trump (www.donaldjtrump.com), disebutkan beberapa rincian program yang akan di jalankan kedepannya. Pada program pajak, Donald Trump akan memotong pajak perusahaan menjadi 15 persen dari semula 35 persen dengan syarat produksi dilakukan di Amerika Serikat serikat. Program lain adalah peninjauan ulang beberapa kesepakatan perdagangan bebas. Program ini dimaksudkan untuk melindungi para produsen asli Amerika Serikat dari ancaman 
produk luar Amerika Serikat, ini tentunya akan merugikan negara pengekspor seperti Indonesia.

Hasil penelitian ini sejalan dengan penelitian yang dilakukan oleh Ghanem dan David (2014), Hatmanti dan Bambang (2017), Mahmood et al., (2015), Najaf et al., (2015), Kabiru et al., (2015), Pamungkas dkk., (2015), Ramesh dan Rajumesh (2015), Sasongko dkk., (2015), Yuliana dan Sudana (2015), yang menemukan terdapat abnormal return setelah peristiwa dalam suatu peristiwa politik yang diteliti.

Berdasarkan pembahasan hasil penelitian, implikasi dari hasil penelitian ini yaitu berimplikasi bagi investor untuk mempertimbangkan informasi mengenai faktor-faktor non ekonomi (peristiwa politik) dalam setiap melakukan keputusan investasi di pasar modal, sebagai salah satu faktor yang mempunyai pengaruh terhadap dinamika pasar modal dan harga saham. Selain itu, hasil penelitian ini menunjukkan bahwa pasar tidak efisien dalam bentuk setengah kuat karena reaksi terjadi berkepanjangan, hal ini berimplikasi bagi investor untuk memperoleh keuntungan (abnormal return) akibat adanya peristiwa politik.

\section{SIMPULAN DAN SARAN}

Peristiwa pengumuman kemenangan Donald Trump dalam Pemilihan Presiden Amerika Serikat 2016 menimbulkan reaksi pasar. Reaksi pasar dapat dilihat dari adanya abnormal return yang signifikan, yaitu pada $\mathrm{H}+1, \mathrm{H}+3, \mathrm{H}+4$ dan $\mathrm{H}+5$. Kecepatan reaksi pasar modal terhadap peristiwa tersebut bereaksi cepat karena terdapat abormal return yang signifikan pada satu hari $(\mathrm{H}+1)$ setelah 
peristiwa. Namun abnormal return muncul kembali pada $\mathrm{H}+3, \mathrm{H}+4$ dan $\mathrm{H}+5$ menunjukkan bahwa pasar tidak efisien, karena reaksi terjadi berkepanjangan.

Berdasarkan hasil pembahasan dan simpulan yang telah dipaparkan, maka saran yang dapat disampaikan adalah bagi para investor disarankan agar dalam mengambil keputusan investasi investor tidak hanya melihat peristiwa politik saja, namun juga memperhatikan faktor-faktor lain yang dapat memengaruhi harga saham. Untuk penelitian selanjutnya disarankan untuk mencoba menggunakan mean adjusted-model dan market model dalam menghitung expected return.

\section{REFERENSI}

Altin, Hakan. 2015. Efficient Market Hypothesis, Abnormal Return and Election Periods. European Scientific Journal. 11(34): 169-178.

Anonim. 2016. We Must Think Big and Dream Even Bigger. https://www.donaldjtrump.com/media/archives/2017/01 (diunduh tanggal 15 April 2017).

Arde, M.Hatta Diman. 2017. Studi Peristiwa Tragedi Sarinah Terhadap Pasar Modal Indonesia. E-Jurnal Manajemen Unud. 6(6): 3080-3110.

Ariyanti, Fiki.2016. Sri Mulyani Ungkap Penyebab Rupiah Anjlok ke 13.800 per Dolar AS. http://bisnis.liputan6.com/read/2649495/sri-mulyani-ungkappenyebab-rupiah -anjlok-ke-13800-per-dolar-as (diunduh 15 April 2017).

Boomgaarden, Hajo., Rens Vliegenthart., Claes de Vreese. 2012. A Worldwide Presidential Election: The Impact of the Media on Candidate and Campaign Evaluations. International Journal of Public Opinion Research. 24 (1): 42-61.

Chien, Wen-Wen Chien., Roger Mayer., Zigan Wang. 2014. Stock Market, Economic Performance, And Presidential Elections. Journal of Business \& Economics Research The Clute Institute. 12(2): 159-170.

Deva, Kumar., Sophia Sharon., Jucunda Evelyn Maria. 2015. Empirical Study on Effects of the Lok Sabha Election on Stock Market Performance (BSE Sensex). Research Journal of Management Sciences. 4(2): 1-9.

Diniar, Ayudia Hanung dan Kiryanto. 2015. Analisis Dampak Pemilu Presiden Jokowi terhadap Return Saham (Studi Kasus Saham LQ-45 di Bursa Efek Indonesia). Jurnal Akuntansi Indonesia. 4(2). 97-108.

Fahmi, Irham. 2012. Manajemen Investasi: Teori dan Soal Jawab. Jakarta: Salemba Empat. 
Ghanem, Davy dan David Rosvall. 2014. Major World Events Impact on Stock Market Prices-An Event Study. Journal Department of Business Studies Uppsala University. 11(2): 430-445.

Hatmanti dan Bambang. 2017. Pengaruh Pelantikan Kabinet Kerja Hasil Reshuffle Jilid II Terhadap Harga Saham LQ-45. Jurnal Economia UGM. 13(1): 1-13.

Hidayah, Restu. 2015. Penerapan Model Treynor Untuk Menentukan Pilihan Investasi Saham yang Efisien (Studi pada Saham Perusahaan LQ-45 di BEI Tahun 2010-2013). Jurnal Administrasi Bisnis. 22(1): 1-8.

Hung, Ling-Chun. 2013. US Presidential Election and the Taiwanese Stock Market. Journal of International Relations National Chengchi University. 49(1): 71-97.

Jogiyanto, Hartono. 2005. Pasar Efisien Secara Keputusan. PT Gramedia Pustaka Utama: Jakarta.

Jogiyanto, Hartono. 2015. Teori Portofolio dan Analisis Investasi. Edisi Kedelapan. BPPE: Yogyakarta.

Kabiru, James Ndungu., Duncan Elly Ochien., Hellen Wairimu Kinyua. 2015. The Effect of General Elections on Stock Returns at Nairobi Securities Exchange. European Scientific Journal, 11(28): 435-460.

Lestarini, Ade Hapsari. 2016. Perdagangan Siang, IHSG Meroket 101 Poin. http://ekonomi.metrotvnews.com/bursa/nbwe3J5K-perdagangan-siang-ihsgmeroket-101-poin (diunduh 15 April 2017).

Mahmood, Shahid., Muhammad Irfan,. Saeed Iqbal., Muhammad Kamran. 2014. Impact of Political Events on Stock Market: Evidence from Pakistan. Journal of Asian Business Strategy. 4(12):163-174

Mayo, Herbert B. 2016. Investmens An Indroduction. New Jersey: Cengage Learning.

Murekachiro, Dennis. 2014. Opinion Polls and The Stock Market: Evidence From The 2013 Zimbabwe Presidential Elections. Journal of Finance. 2(4):1-9.

Najaf, Khakan., Rabia Najaf., Amir Iqbal., Imran Hussain Shah. 2015. The Impact of Terrorism And Political Events On Stock Market: Empirical Evidence From Pakistan. International Journal of Scientific Research and Management. 3(6): 3036-3045.

Octafilia, Yusnita. 2016. Dampak Pemilihan Presiden Republik Indonesia Tahun 2014 Terhadap Abnormal Return dan Trading Volume Activity di Bursa Efek Indonesia (Event Study Pada Saham Indeks Kompas 100). E-journal Pelita Indonesia. 1(1): 100-110.

Pamungkas, Aryo,. Suhandak., Wi Endang. 2015. Pengaruh Pemilu Presiden Indonesia Tahun 2014 Terhadap Abnormal Return dan Trading Volume Activity (Studi Pada Perusahaan yang Tercatat Sebagai Anggota Indeks Kompas100). Jurnal Administrasi Bisnis Universitas Brawijaya. 20(1): 1-9. 
Ramesh, S danRajumesh. 2015. Stock Market Reaction to Political Events:A Study of Listed Companies in Colombo Stock Exchange of Sri Lanka. Journal of Economics and Sustainable Development. 6(3): 131-140.

Samsul, Muhammad. 2015. Pasar Modal dan Manajemen Portofolio. Edisi 2. Jakarta: Erlangga.

Sasongko, Jovialco., Marlina Widiyanti., Taufik. 2015. Reaksi Pasar Modal Atas Peristiwa Pengumuman Presiden RI 2014 (Studi pada Saham Sektor Pertambangan di Bursa Efek Indonesia). Jurnal Ilmiah Manajemen Bisnis dan Terapan. 12(1): 33-44.

Saputra, Indra. 2016. Analisis Perbedaan Rata-Rata Trading Volume Activity Saham Sebelum dan Sesudah Pemilu Presiden dan Wakil Presiden Tahun 2014 (Saham LQ-45 di Bursa Efek Indonesia Periode 29 Juni - 19 Juli 2014). Jurnal Ekonomi dan Bisnis. 9(1): 76-86.

Silitonga, Linda Teti. 2016. Trump Presiden Terpilih AS: Pidato Kemenangan Nyamankan Pasar, Trump Serukan Persatuan. http://finansial.bisnis.com/read/20161110/9/601093/trump-presiden-terpilihas-pidato-kemenangan-nyamankan-pasar-trump-serukan-persatuan (diunduh 15 April 2017).

Tandelilin, Eduardus. 2010. Analisis Investasi dan Manajemen Portofolio. Edisi Pertama. Kanisius:Yogyakarta.

Segara, Tirta. 2016. Ekonomi Triwulan III 2016 Tumbuh 5,02\%. http://www.bi.go.id/id/ruang-media/siaran-pers/Pages/sp_188916.aspx(diunduh tanggal 15 April 2017).

Yuliana, Yovinda Trista dan Sudana. 2015. Reaksi Pasar Saham Terhadap Peristiwa Politik di Parlemen Indonesia Tahunn 2014 (Studi Peristiwa Pada Perusahaan Yang Terdaftar Di BEI). Jurnal Manajemen Bisnis Indonesia. 3(1): 14-28.

Yuniarthi dan Sujana. 2016. Reaksi Pasar Modal Terhadap Pencalonan Jokowi Menjadi Presiden Republik Indonesia. E-Jurnal Akuntansi Universitas Udayana. 16(2): 951-977.

Waterschoot, Joep. 2013. An Empirical Study on The Impact of The U.S Presidential Election On the U.S. Stock Market. Journal Economic and Management Finance Department Tilburg University. 8(2): 153-169.

Wagner, Alexander F., Richard J. Zeckhauser., Alexandre Ziegler. 2017. Company Stock Reactions to the 2016 Election Shock. Journal of Series Harvard University. 1(4): 67-79.

Winarno, Tri. 2016. Meredam Trump Effect. http://ekonomi.metrotvnews.com/meredam-trump-s-effect (diunduh tanggal 15 April 2017).

Wolfers, Justin dan Zitzewits Eric. 2016. What do Financial Markets Think of The 2016 Election?. Journal University of Michigan. 14(2): 552-570. 
Kadek Ria Kusumayanti, Reaksi Pasar Modal ...

Wong, Wai-Yan dan Chee-Wooi Hooy. 2016. The Impact of Election on Stock Market Returns of Government-Owned Banks: The Case of Indonesia, Malaysia and Thailand. Asian Journal of Business and Accounting. 9(1): 3158. 